\title{
INTERVENSI ISOFLAVON KEDELAI TIDAK BERPENGARUH TERHADAP STATUS INFLAMASI DAN IMUNITAS PADA REMAJA DENGAN KEGEMUKAN
}

\author{
(Soy Isoflavone Intervention Did Not Affect the Inflammation Status and Immunity of \\ Overweight/Obese Teenagers)
}

Mira Dewi ${ }^{1 *}$, Ali Khomsan ${ }^{1}$, dan Dadang Sukandar ${ }^{1}$

1* Alamat korespondensi: Departemen Gizi Masyarakat, Fakultas Ekologi Manusia, Institut Pertanian Bogor, Bogor 16680. Telp: 0251-8621258; Fax: 0251-8622276; Email: miradewi2006@yahoo.co.id

1 Departemen Gizi Masyarakat, Fakultas Ekologi Manusia, Institut Pertanian Bogor, Bogor 16680.

\begin{abstract}
Overweight/obesity is a condition that has been proven to be interrelated with chronic inflammation and compromised immune system due to disregulation of adipocytokine. The aim of the present study was to evaluate the effect of soy isoflavone on the markers of inflammation and immunity of overweight or obese teenagers. Eighteen overweight or obese teenagers, 9 boys and 9 girls each sex were randomized to one of three intervention groups; $0 \mathrm{ml}, 150 \mathrm{ml}$ and $300 \mathrm{ml}$ soy milk, equal to $0 \mathrm{~g}, 25 \mathrm{~g}$ and $50 \mathrm{mg}$ isoflavone everyday for 30 days. The data collected were food consumption, plasma isoflavone concentration, plasma IL6 as indicator of inflammation, and lymphocyte and NK cell count as indicator of immunity. The study showed that nutrient intake of samples were still relatively low. The soy milk intervention significantly increased plasma isoflavone concentration, but not significantly had contribution to the plasma IL6 concentration and lymphocyte and NK cell count. Several kind of food consumed by samples had contribution to the plasma isoflavone concentration, and lymphocyte count. Based on the results, it was suggested that soy isoflavone intervention does not affect the inflammation status and immunity of overweight/obese teenagers.
\end{abstract}

Key words: Overweight/obesity, teenagers, soy isoflavone, inflammation, immunity

\section{PENDAHULUAN}

Prevalensi kegemukan pada remaja dilaporkan terus meningkat pada seluruh bagian dunia (Speiser 2005). Di Indonesia, berdasarkan laporan Riset Kesehatan Dasar 2007, prevalensi obesitas atau kegemukan dengan indeks massa tubuh (IMT) lebih dari 30 pada penduduk usia > 15 tahun adalah 18,8 \% dan angka ini meningkat dari tahun ke tahun (Depkes 2008). Hal yang sama diduga terjadi pada penduduk kelompok anak dan remaja (Dwiriani 2006), dan dikhawatirkan akan berakibat pada meningkatnya berbagai komplikasi penyakit seperti diabetes melitus tipe 2 dan kardiovaskular pada usia yang lebih lanjut. Saat ini penyakit-penyakit termasuk penyebab kematian paling banyak di dunia dan memakan biaya yang sangat besar untuk penanggulangannya serta secara nyata menurunkan kualitas hidup penderitanya (Satoto 1998). Komplikasi pada masa dewasa sulit untuk disembuhkan sehingga pencegahan sejak dini pada masa remaja menjadi sangat penting untuk dilakukan (Caterina 2006; Cole 2000; Dietz 1997).

Sel lemak atau adiposit memproduksi berbagai macam adipositokin. Pada obesitas, terdapat penurunan produksi beberapa faktor yang dalam keadaan normal disintesis oleh adiposit seperti adiponektin dan sebaliknya terdapat peningkatan pelepasan adipositokin lain seperti resistin, angiotensinogen, plasminogen activator inhibitor-1, TNF $\alpha$, ILs, leptin dan lain-lain (Bays 2002). Pada keadaan demikian, sel lemak menjadi 'disfungsional' (Kantartzis 2006). Lemak disfungsional ini menghasilkan antara lain mediator inflamasi yang akan mengakibatkan timbulnya inflamasi kronis (Soobratte 2005). Interleukin-6 (IL6), salah satu sitokin inflamasi, diekspresikan dalam jumlah besar di jaringan adiposit dan memainkan peran penting dalam inflamasi dan pengaturan fungsi sel $T$ dan sel $B$. 
Berbagai penelitian menunjukkan bahwa isoflavon, senyawa antioksidan turunan fenol yang banyak terdapat pada kedelai dan jenis polong-polongan lain memiliki manfaat positif terhadap kondisi inflamasi dan memperbaiki fungsi imun baik in vitro maupun in vivo (Borchers 2006). Keadaan-keadaan ini merupakan dasar kelainan yang terjadi pada kegemukan, namun sejauh ini belum ditemukan laporan penelitian mengenai manfaat isoflavon maupun kedelai terhadap kondisi kegemukan, baik pada hewan maupun manusia. Kedelai sendiri merupakan sumber makanan yang banyak tersedia, mudah didapat dan terjangkau oleh masyarakat sehingga berpotensi untuk membantu mengatasi masalah tersebut.

Tujuan utama studi ini adalah untuk mengevaluasi efek isoflavon kedelai terhadap penanda inflamasi dan imunitas pada kelompok remaja usia 12-16 tahun dengan kegemukan atau Indeks Masa Tubuh (IMT) menurut umur di atas normal. Penelitian ini diharapkan akan mempunyai arti penting untuk perbaikan diet pada remaja-remaja gemuk sehingga dapat negatip kegemukan dapat diatasi.

\section{METODE}

\section{Desain, Tempat, dan Waktu}

Penelitian dilakukan di sekolah setingkat SMP di kota Bogor selama 6 bulan, dari bulan Juli - Desember 2009. Penelitian dilakukan pada anak remaja berusia 12-16 tahun yang memiliki Indeks Massa Tubuh menurut umur termasuk kategori overweight atau obese.

Penelitian ini merupakan bagian dari penelitian mengenai efektivitas isoflavon kedelai untuk memperbaiki penanda inflamasi, stres oksidatif dan status imun pada remaja dengan kegemukan. Penentuan banyaknya ulangan didasarkan pada nilai rata-rata dan simpangan konsentrasi malondialdehida plasma sebagai parameter stres oksidatif dengan rumus sebagai berikut

$$
n=\frac{\left(Z_{\alpha}+Z_{\beta}\right)^{2} 2 \sigma^{2}}{\delta^{2}}
$$

keterangan:

$Z_{\alpha}=$ suatu nilai sehingga $P\left(Z>Z_{\alpha}\right)=1-\alpha, Z$ adalah peubah acak normal baku

$\mathrm{Z}_{\beta}=$ suatu nilai sehingga $\mathrm{P}\left(\mathrm{Z}>\mathrm{Z}_{\beta}\right)=1-\beta, \mathrm{Z}$ adalah peubah acak normal baku

Dengan mengambil $\alpha=0.05$, power test $1-\beta=0.84$ lalu disubstitusikan ke dalam formula di atas maka dapat ditentukan jumlah ulangan $\mathrm{n}=3.4596$. Banyaknya kelompok adalah 2 (lakilaki dan perempuan) $\times 3$ taraf sehingga jumlah keseluruhan subjek adalah 18 orang.

\section{Bahan}

Bahan intervensi yang digunakan adalah susu kedelai merek $S$ yang setelah dianalisis diketahui mengandung isoflavon sebanyak $0.17 / \mathrm{mL}$. Untuk mencapai dosis yang diinginkan yakni $25 \mathrm{~g}$ dan $50 \mathrm{~g} /$ hari isoflavon serta mempertimbangkan kemudahan teknis pemberian, maka diberikan susu kedelai sebanyak 0 $\mathrm{ml}$ (kontrol), $150 \mathrm{ml}$ dan $300 \mathrm{ml}$ setiap hari selama 30 hari pada masing-masing kelompok perlakuan.

\section{Jenis dan Cara Pengumpulan Data}

Sebelum intervensi, pada sampel akan dilakukan wawancara mengenai data riwayat kesehatan keluarga dan konsumsi serta pemeriksaan fisik dan analisis darah. Pemeriksaan fisik dan analisis darah kembali dilakukan pada akhir intervensi.

Konsentrasi isoflavon pada plasma diukur dengan metode High Performance Liquid Chromatography. Sampel plasma dianalisa untuk IL6 dengan metode ELISA. Hitung limfosit dan sel NK diukur berdasarkan analisis dual-color flow cytometric.

\section{Pengolahan dan Analisis Data}

Sesuai dengan model matematis yang telah dirumuskan maka analisis kovarians pada rancangan acak kelompok dapat dilakukan dengan prosedur General Linear Model (GLM) yang ada pada SAS. Selanjutnya analisis regresi akan dilakukan untuk memperoleh persamaan matematis antara kadar isoflavon serum setelah percobaan, kadar IL 6 serum setelah percobaan, dan jumlah sel limfosit dan sel NK setelah percobaan dengan volume susu kedelai yang diberikan dan semua peubah pengganggu untuk remaja laki-laki dan remaja perempuan.

\section{HASIL DAN PEMBAHASAN}

Konsumsi, Angka Kecukupan Gizi, dan Tingkat Kecukupan Energi dan Protein

Pada responden dengan perlakuan susu kedelai $0 \mathrm{ml}$, tingkat kecukupan energi dan protein masing-masing hanya mencapai $67 \%$ dan $72.6 \%$. Ini mengindikasikan masih kurangnya asupan gizi penting penunjang pertumbuhan anak. Sementara itu, pada responden dengan perlakuan susu kedelai $150 \mathrm{ml}$, tingkat kecukupan protein sudah melebihi 100\% yakni 
119.1\% tetapi tingkat kecukupan energi masih kurang dari $100 \%$ yakni hanya $72 \%$. Pada responden dengan perlakuan susu kedelai 300 $\mathrm{ml}$, keragaannya hampir sama dengan responden susu kedelai $0 \mathrm{ml}$ (tingkat kecukupan energi 61\%, protein $81.8 \%$ ).

Rendahnya asupan energi bisa terjadi karena mungkin mereka sedang diit. Sampel dalam penelitian ini semuanya dalam kondisi overweight atau obes. amun bisa juga terjadi karena sampel suka jajan yang mengenyangkan meski sebenarnya asupan energinya masih kurang.

Secara keseluruhan hal ini menunjukkan bahwa asupan gizi yang paling baik adalah pada kelompok dengan perlakuan susu kedelai $150 \mathrm{ml}$. Ketidakcukupan gizi di kalangan siswa harus mendapat perhatian serius sebab mereka masih dalam tahap pertumbuhan. Oleh sebab itu, makan dengan jumlah yang cukup terutama makan di rumah dan tidak hanya mengandalkan jajanan di sekolah perlu ditekankan kepada mereka sebagai hal penting yang harus diperhatikan.

\section{Konsentrasi Isoflavon Plasma}

Konsentrasi isoflavon secara sangat nyata dipengaruhi oleh pemberian susu kedelai sebagai faktor. Hal ini serupa dengan beberapa penelitian terdahulu (Borchers et al 2005). Dari persaman regresi didapatkan koefisien susu kedelai bernilai positif, hal ini menunjukkan bahwa semakin tinggi konsumsi susu kedelai maka semakin tinggi pula konsentrasi isoflavon plasma (tabel 2,3,4). Sebaliknya, koefisien ubi jalar bernilai negatif, hal ini berarti bahwa semakin tinggi frekuensi konsumsi ubi jalar maka semakin rendah nilai konsentrasi isoflavon plasma. Model regresi ini dapat menjelaskan $63 \%$ keragaman isoflavon plasma dengan rincian $36 \%$ dijelaskan oleh susu kedelai yang diminum dan $27 \%$ dijelaskan oleh frekuensi konsumsi ubi

Tabel 1. Statistik Konsumsi, Angka Kecukupan dan Tingkat Kecukupan Gizi Subyek

\begin{tabular}{|c|c|c|c|c|c|c|}
\hline \multirow{2}{*}{ Zat Gizi } & \multicolumn{2}{|c|}{ Konsumsi } & \multicolumn{2}{|c|}{ Angka Kecukupan Gizi } & \multicolumn{2}{|c|}{ Tingkat Kecukupan } \\
\hline & Mean & SD & Mean & SD & Mean & SD \\
\hline \multicolumn{7}{|l|}{$0 \mathrm{~mL}$} \\
\hline Energi (kkal) & 1535 & 689 & 2250 & 164 & 67 & 27 \\
\hline Protein (g) & 45.9 & 20.2 & 63.0 & 1.1 & 72.6 & 31.3 \\
\hline \multicolumn{7}{|l|}{$150 \mathrm{~mL}$} \\
\hline Energi (kkal) & 1535 & 689 & 2250 & 164 & 67 & 27 \\
\hline Protein (g) & 45.9 & 20.2 & 63.0 & 1.1 & 72.6 & 31.3 \\
\hline \multicolumn{7}{|l|}{$300 \mathrm{~mL}$} \\
\hline Energi (kkal) & 1535 & 689 & 2250 & 164 & 67 & 27 \\
\hline Protein $(\mathrm{g})$ & 45.9 & 20.2 & 63.0 & 1.1 & 72.6 & 31.3 \\
\hline
\end{tabular}

Tabel 2. Analisis Ragam Model Regresi Konsentrasi Isoflavon Plasma Akhir sebagai Peubah Tak Bebas

\begin{tabular}{lrrrrr}
\hline \multicolumn{1}{c}{ Sumber keragaman } & Derajat bebas & $\begin{array}{c}\text { Jumlah } \\
\text { kuadrat }\end{array}$ & $\begin{array}{c}\text { Kuadrat } \\
\text { tengah }\end{array}$ & F hitung & Peluang \\
\hline Regresi & 2.00 & 27.14 & 13.57 & 11.16 & 0.00 \\
Galat & 13.00 & 15.80 & 1.22 & & \\
Total & 15.00 & 42.94 & & & \\
\hline
\end{tabular}

Tabel 3. Persamaan Regresi Konsentrasi Isoflavon Plasma Akhir

\begin{tabular}{lcccc}
\hline \multicolumn{1}{c}{ Variabel Independen } & $\begin{array}{c}\text { Parameter } \\
\text { estimate }\end{array}$ & Standard error & F hitung & Peluang \\
\hline Intercep & 1.69 & 0.45 & 14.16 & 0.00 \\
Susu kedelai & 0.01 & 0.00 & 18.44 & 0.00 \\
Ubi & -0.89 & 0.29 & 9.49 & 0.01 \\
\hline
\end{tabular}


Tabel 4. Kontribusi Peubah Bebas terhadap Konsentrasi Isoflavon Plasma Akhir

\begin{tabular}{lcccc}
\hline \multicolumn{1}{c}{ Variabel Independen } & R2 Parsial & R2 Model & F hitung & Peluang \\
\hline Susu kedelai & 0.36 & 0.36 & 7.99 & 0.01 \\
Ubi & 0.27 & 0.63 & 9.49 & 0.01 \\
\hline
\end{tabular}

Pengaruh negatif dari konsumsi ubi jalar terhadap konsentrasi isoflavon plasma belum dapat dijelaskan, apakah ubi jalar mengandung unsur atau senyawa yang berinteraksi langsung dengan isoflavon atau mempengaruhi penyerapannya perlu diselidiki lebih lanjut.

\section{Konsentrasi Interleukin 6 Plasma}

Pada penelitian ini, pemberian intervensi susu kedelai tidak mempengaruhi konsentrasi IL6 plasma pada semua kelompok. Studi oleh Jenkins menunjukkan bahwa diet mengandung isoflavon dosis tinggi (73 mg/ hari) meningkatkan konsentrasi IL6 pada subjek usia menengah baik laki-laki maupun perempuan, namun dosis rendah (10 mg/hari) tidak. Tidak terlihatnya pengaruh susu kedelai terhadap konsentrasi IL6 pada penelitian ini dapat disebabkan beberapa hal, yaitu; pertama, subyek merupakan kelompok remaja di mana kegemukan yang dialami kemungkinan besar belum berupa penumpukan adiposit yang disfungsional, sehingga status inflamasi karena ketidak seimbangan hormon yang dilepaskan oleh sel-sel adiposit belum terlihat nyata, begitu pula belum terdapat gangguan yang nyata pada sistem imun, serta perubahan endotel yang berarti. Kedua, dosis isoflavon yang diberikan belum cukup tinggi untuk menimbulkan perubahan. Ketiga, terdapat perbedaan mekanisme interaksi estrogen dengan reseptornya atau metabolisme isoflavon dalam tubuh pada subyek remaja dan dewasa, terutama dengan kelompok menopause. Keempat, ekspresi IL6 tidak secara langsung dipengaruhi oleh isoflavon seperti halnya IFN $\gamma$.

\section{Hitung Limfosit dan Sel NK}

Hasil analisis hitung limfosit dan sel NK sebelum intervensi menunjukkan tidak ada perbedaan signifikan antar kelompok perlakuan. Hitung sel NK akhir secara sangat nyata dipengaruhi oleh hitung sel NK awal dan frekuensi konsumsi pisang. Dari persamaan regresi dapat dilihat bahwa koefisien hitung sel NK akhir dan frekuensi konsumsi pisang bernilai positif, hal ini menunjukkan bahwa semakin tinggi hitung sel NK awal dan frekuensi konsumsi pisang maka semakin tinggi pula hitung sel NK akhir. Model regresi ini dapat menjelaskan $87 \%$ keragaman hitung sel NK akhir dengan rincian $70 \%$ dijelaskan oleh hitung sel NK awal dan $27 \%$ dijelaskan oleh frekuensi konsumsi pisang. Pisang diketahui mengandung beberapa zat gizi yang bermanfaat untuk kesehatan, namun perannya yang spesifik terhadap sistem imun khususnya pada remaja gemuk sejauh ini belum diteliti.

Secara keseluruhan, pada penelitian ini pemberian susu kedelai tidak memberi pengaruh signifikan pada hitung limfosit mau pun sel NK. Keragaman parameter sistem imun pada akhir perlakuan lebih disebabkan oleh berbagai macam konsumsi pangan. Lebih jauh lagi, keragaman sangat dipengaruhi oleh faktor lain seperti adanya infeksi sub klinis yang tidak diperhitungkan dalam analisis.

Studi-studi pada hewan percobaan dan manusia menunjukkan bahwa isoflavon dapat mempengaruhi subset limfosit (Møller 1998). Pada mencit yang diberi genistein, terdapat peningkatan aktivitas sel NK. Peningkatan aktivitas sel NK juga terjadi pada Sprague Dawley betina yang diberi makan genistein. Begitu pula pada wanita yang diberi daidzein dan genistein. Mekanisme dugaannya adalah imunoregulasi melalui aksi estrogenik. Pada penelitian ini hal yang serupa tidak terbukti, dan diduga disebabkan perbedaan aktivitas estrogen pada kelompok remaja. Selain itu, dosis yang diberikan lebih rendah dari penelitian sebelumnya di mana aktivitas sel NK meningkat.

\section{KESIMPULAN}

1. Asupan energi dan protein subyek secara keseluruhan masih kurang.

2. Pemberian susu kedelai dengan dosis seperti dalam penelitian ini secara nyata meningkatkan kadar isoflavon plasma

3. Susu kedelai tidak berpengaruh terhadap kadar IL6, hitung limfosit dan sel NK yang merupakan indikator status inflamasi dan imunitas. 


\section{UCAPAN TERIMA KASIH}

Peneliti mengucapkan terimakasih kepada Dirjen Dikti yang telah mendanai penelitian ini, pihak sekolah SMP Bina Insani Bogor beserta siswa dan orang tua siswa atas ijin dan bantuannya dalam melaksanakan penelitian, Laboratorium Makmal Terpadu Imunoendokrinologi FKUI Jakarta, dan laboratorium Bioteknologi LIPI Bogor atas bantuannya dalam analisis serta para asisten dan mahasiswa atas bantuan teknis di lapangan hingga penyusunan laporan.

\section{DAFTAR PUSTAKA}

Bays. 2002. Role of the adipocyte, free fatty acids, and ectopic fat in pathogenesis of type 2 diabetes mellitus: peroxisomal proliferator-activated receptor agonists provide a rational therapeutic approach. Journal of Endocrinology \& Metabolism 89(2), 463-478.

Borchers TA. 2006. Soy isoflavones modulate immune function in healthy postmenopausal women. American Journal of Clinical Nutrition, 83(2), 421S-426S.

Caterina R. 2006. Nutritional mechanisms that influence cardiovascular disease. American Journal of Clinical Nutrition, 83(5), 1118-1125.

Cole TJ. 2000. Establishing a standard definition of childhood overweight and obesity worldwide. International Survey. $\mathrm{Br}$ Med J 320, 1240-1243.
Depkes 2008. Riset Kesehatan Dasar 2007. Departemen Kesehatan Republik Indonesia, Jakarta.

Dietz, WH. 1997. Periods of risk in childhood for the development of adult obesity. What do we need to learn. J Nutr 127, 1884-1886.

Dwiriani CM. 2006. Faktor-faktor yang Berpengaruh terhadap Kegemukan Pada Anak. Review Literatur. Sekolah Pascasarjana IPB, Bogor.

Kantartzis K. 2006. The relationships of plasma adiponectin with a favorable lipid profile, decreased inflammation, and less ectopic fat accumulation depend on Adiposity. Clinical Chemistry. 52, 19341942.

Satoto S. 1998. Kegemukan, Obesitas dan Penyakit Degeneratif: Epidemiologi dan Strategi Penanggulangannya. Di dalam Prosiding Widya Karya Nasional Pangan dan Gizi VII. LIPI, Jakarta.

Soobratte MA. 2005. Phenolics as potential antioxidant therapeutic agents: mechanism and actions. Mutation Research 579, 200-213.

Speiser PW et.al. 2005. Consensus statement: childhood obesity. J Clinic Endocrinol \& Metab 90(3), 1871-1881. 